\title{
Uma conjugação energético-ambiental para um megarreflorestamento no Brasil
}

\section{JOSÉ OTAVTO BRTTO*}

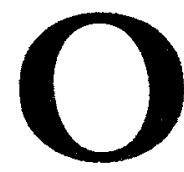

Instituto de Estudos Avançados da USP lançou recentemente a proposta de um megarreflorestamento a ser executado em nosso País, com o objetivo principal da absorçáo do excesso de $\mathrm{CO}_{2}$ da atmosfera. Na proposta está bem evidenciado o fato de que o reflorestamento, na ordem de $\mathbf{2 0}$ milhóes de hectares, somente terá sentido nesse seu objetivo maior se forem adotadas medidas definitivas quanto à necessidade do uso de fontes energéticas alternativas tais como hidrogênio, energia solar e fusáo nuclear. No entanto, é preciso considerar que as informaçóes mais recentes indicam que o petróleo continuará sendo, em nível mundial, a fonte predominante de energia até a metade do século XXI. Da mesma forma, o carvão mineral continuará a ter importante e talvez crescente papel. Apesar da importância e vantagens ambientais, há firmes indicaçóes de que as energias alternativas não representaráo em futuro próximo a maior parcela do suprimento mundial de energia. Vale ainda lembrar que, conforme consta na própria proposta do Projeto FLORAM, a ordem de grandeza do tempo disponível para a reversão dos níveis de $\mathrm{CO}_{2}$ na atmosfera é extremamente escassa para as transformaçóes energéticas disponíveis, principalmente diante dos custos e demais impactos que tais transformaçóes representam.

Diante desse quadro, cremos que o Projeto FLORAM, na idéia da conjugaçáo da questão energética com a questão ambiental, poderia conter um objetivo diferente, talvez inédito. Estamos nos referindo à oportunidade de que seja lançada, junto com o megarreflorestamento, a idéia da valorização e intensificação do uso da biomassa florestal para fins energéticos.

* José Otávio Brito é professor do Departamento de Ciências Florestais da ESALQ/USP. 
É que no Brasil, em razão da tradição, há um perfeito conhecimento quanto ao emprego da biomassa florestal para finalidades energéticas.
Em primeiro lugar, através do megarreflorestamento estaria garantido um considerável volume de madeira para o abastecimento contínuo e sustentado de energia para o nosso país, sem nenhuma dependência externa. Em segundo lugar, seria possível obter-se o desejado equilíbrio entre a quantidade de $\mathrm{CO}$, eliminado mediante a queima da madeira em suas diversas aplicaçóes energéticas, e a quantidade de $\mathrm{CO}_{2}$ que estaria sendo absorvida pelas próprias florestas implantadas para tal utilizaçăo. Estaria assim alcançado o equilíbrio no balanço de $\mathrm{CO}_{2}$ na atmosfera, ao contrário do que ocorre atualmente com o uso dos combustíveis fósseis, eminentemente apenas emissores de $\mathrm{CO}_{2}$.

É importante frisar que, particularmente para o nosso país, o emprego da biomassa florestal para energia resultaria em impactos sensivelmente menores que aqueles decorrentes das transformaçóes $\mathrm{e}$ dos custos envolvidos na adoção das chamadas fontes novas de energia. É que no Brasil, em razão da tradição, há um perfeito conhecimento quanto ao emprego da biomassa florestal para finalidades energéticas. Haveria apenas necessidade de pequenos aperfeiçoamentos e otimizações de tecnologias que, diga-se de passagem, estáo totalmente disponíveis em nosso país.

A título ilustrativo, vejamos o que poderia resultar se a idéia exposta fosse aplicada ao Projeto FLORAM.

O Projeto apresenta dados que indicam a possibilidade da captaçáo média de 7,7 t de Carbono/ano por hectare de floresta implantada, através do consumo fotossintético de $\mathrm{CO}$. Esse Carbono é fixado na árvore, na proporçáo de $50 \%$ da matéria seca produzida.

Conseqüentemente, a quantidade total de matéria seca resultante seria de $15,4 \mathrm{t} /$ ano por hectare de floresta implantada. Considerando-se somente o fuste das árvores, a produção seria de $10 \mathrm{t}$ de matéria seca/ano por hectare. Se essa madeira fosse usada para fins energéticos. haveria em consequiência um potencial de liberaçáo de $\mathrm{CO} 2$, na devida proporçáo de $5 \mathbf{t}$ de Carbono/ano por hectare de floresta explorada. Tal valor estaria perfeitamente compatível com a capacidade de absorção fotossintética de $\mathrm{CO}_{2}$ anteriormente indicada se, na proporção do uso da madeira, corresse a devida reposiçáo florestal. Estaria assim garantido o equilíbrio entre a emissão e a absorção para o ciclo de $\mathrm{CO} 2$. Se, teoricamente, toda a madeira dos 20 milhóes de hectares do Projeto FLORAM fosse explorada para uso energético, e considerado um ciclo de rotaçáo florestal de $\mathbf{5}$ anos, seria possível o corte anual de 4 milhóes de hectares. Com base na hipótese anteriormente considerada da exploração de $10 \mathrm{t}$ de madeira/ano por

Estudos Avançados, 4(9) 
hectare, haveria a possibilidade da obtenģäo anual de $\mathbf{4 0}$ milhōes de $t$ ou 80 milhọes de metros cúbicos sólidos de madeira. Esse seria o volume de madeira a ser usado para energia, no sentido da manutençáo do equilíbrio de $\mathrm{CO}_{2}$ na atmosfera. A título de comparaçáo, tal volume garantiria o suprimento de cerca de $50 \%$ do atual consumo brasileiro de madeira para energia, ou o equivalente a $20 \%$ do consumo nacional de combustíveis fósseis, representados pelo petróleo, carvão mineral, coque e gás natural. 